\title{
Antifungal properties of lactic acid bacteria isolated from cocoa beans fermentation in the centre region of Cameroon
}

\author{
SANDRINE AIMÉE YOUTE FANCHE ${ }^{1,2}$, ANTOINE LAURENT WOUAPI TCHOKONTHE ${ }^{1}$, \\ CAMELIA FILOFTEIA DIGUȚA ${ }^{2}$, SYLVAIN LEROY SADO KAMDEM ${ }^{1}$, FLORENTINA \\ ISRAEL-ROMING ${ }^{2}$, FLORENTINA MATEI $^{2}$, JEAN-JUSTIN ESSIA NGANG $^{1}$
}

\author{
${ }^{1}$ University of Yaoundé I, Faculty of Sciences, Microbiology Department, Fax 237.222.234.496, \\ PO Box 812 Yaounde, Cameroon \\ ${ }^{2}$ University of Agronomic Sciences and Veterinary Medicine Bucharest, Faculty of Biotechnologies, \\ 59 Marasti Blvd., Fax.004-021-318.25.88, Bucharest, district 1, Romania
}

\begin{abstract}
The objective of this study was to identify lactic acid bacteria (LAB) with antifungal activity usable in the fermentation of cocoa beans to limit the moulds growth and to characterize their inhibitory mechanism. A total of $28 \mathrm{LAB}$ strains were isolated from fermented cocoa beans and tested for their antifungal activity against 10 moulds of the genus Aspergillus and Penicillium. An initial selection was made using the transversal method and the inhibition percentage was determined. The most active isolates were subjected to biochemical and molecular analysis; their cell free supernatant was analysed by HPLC and submitted to various treatments (acid neutralization, heat and enzymes). The best lactic acid selection has been subjected to molecular identification and were identified by molecular tools and belong to the species Lactobacillus farciminis, Lactobacillus brevis, Pediococcus pentosaceus, Weissella cibaria and Enterococcus faecium.
\end{abstract}

Keywords Cocoa, moulds, biological control, bacteria compounds.

To cite this article: YOUTE FANCHE SA,, WOUAPI TCHOKONTHE AL, DIGUTA CF, SADO KAMDEM SL, ISRAEL-ROMING F, MATEI F, ESSIA NGANG J-J. Antifungal properties of lactic acid bacteria isolated from cocoa beans fermentation in the centre region of Cameroon. Rom Biotechnol Lett. 2020; 25(2): 1407-1417. DOI: 10.25083/rb1/25.2/1407.1417

*Corresponding author: CAMELIA FILOFTEIA DIGUȚĂ, University of Agronomic Sciences and Veterinary Medicine Bucharest, Faculty of Biotechnologies, 59 Marasti Blvd., Bucharest, district 1, Romania, Fax.004-021-318.25.88

E-mail: camifilo@yahoo.com 


\section{Introduction}

Dried cocoa beans are the raw material used in chocolate industry. In the fresh state, they are seeds coated with a white mucilaginous pulp consisting of approximately $80 \%$ water, $1.5 \%$ pectin, $2 \%$, citric acid, $2.5 \%$ protein, $0.05 \%$ magnesium sulphate, $0.02 \%$ manganese sulphate. The sugar content vary between 10 to $20 \%$ and the $\mathrm{pH}$ from 3.5 to 5.5 depending of pods' age and season $[1,2]$.

Cocoa is one of the most important agriculture commodity products; the cocoa beans quality is highly dependent on processing technologies and storage conditions for preventing the defective quality [3]. The beans are then taken out from the harvested cocoa pods, fermented and dried out before they are sold in the market [4]. The fermentation and drying phases are particularly important since they contribute to the development of aroma and flavour precursors which develop later during the roasting of the beans and for preserving the quality of the raw beans $[5,6,7]$. Mould contamination of food and feed is difficult to be predicted because it depends on a complex interaction of factors, such as temperature, moisture, endogenous fungal species, storage history and storage time [8, 9]. Generally, poor post-harvest management can lead to rapid quality deterioration by the initiation of fungal activity [10]. The biological control methods which have low impact on the consumers' health, have received increasing interest in the recent past in the recent past. Several natural environments have proven to be reservoirs of LAB strains with antifungal properties $[10,11,12]$. In this idea, the use of lactic acid bacteria isolated during cocoa fermentation process as biocontrol agents is of interest, being a plausible alternative due to the antimicrobial component they produce $[10,12,13]$. This study aimed at screening the antifungal activity potential of some lactic acid bacteria (LAB) isolated during cocoa beans fermentation and to characterise some of their biologically active compounds.

\section{Materials and Methods}

\section{(1) Microorganisms origin}

The LAB strains were isolated from fermented cocoa beans collected during heap fermentations conducted by farmers of two villages around Yaoundé and Bafia in the central region of Cameroon.

Therefore, $25 \mathrm{~g}$ of collected samples were washed in $225 \mathrm{ml}$ sterile $\mathrm{NaCl} 0.9 \%$ (w/v) solution. The solutions obtained were subjected to several decimal dilutions and inoculated in MRS Broth (Man, Rogosa, Sharp) (Merck, USA) adjusted to $\mathrm{pH} 6.2$ and supplemented with agar $(1.5 \%)$ and nystatin $\left(0.5 \mathrm{~g} .1^{-1}\right)$ to inhibit moulds growth. The plates were incubated for 48 hours at $37^{\circ} \mathrm{C}$.
The colonies were purified by streaking on the same medium. Only Gram-positive, non-spore forming and catalase negative bacterial isolates were selected and stored at $-80^{\circ} \mathrm{C}$ in MRS broth media supplemented with $30 \%$ glycerol (v/v) for subsequent uses.

Three other strains were used as antifungal positive control based on a previous study [10], namely: Lactobacillus plantarum B-4496 (offered by the Agricultural Research Service (ARS) culture collection of the US Department of Agriculture), Lactobacillus brevis 207 and Lactobacillus sanfranciscensis BB12 (offered by the Laboratory of Microbiology of Food science of the University of Bologna, Cesena campus).

Ten moulds were used to screen the antifungal activity of our studied LAB, of which two (Aspergillus carbonarius NRRL 368, and A. niger NRRL 612) were provided by the ARS culture collection and eight strains were previously isolated from cocoa beans and identified as A. flavus AF, A. tamarii M21, A. fumigatus M11, A. versicolor M14, A. versicolor M22, A. oryzae M13, Penicillium citrinum M7, $P$. citrinum M8. All of these moulds were stored on slants of Potatoes Dextrose Agar (PDA) (Vwr, USA) at $25^{\circ} \mathrm{C}$.

\section{(2) Selection of Antifungal LAB strains}

The inhibitory properties of LAB was tested by transversal assay as described by Laref and Guessas [14] with slight modifications. LAB was streaked in two lines of four centimetres apart in an MRS agar Petri dish (Fig. 1) and incubated for $48 \mathrm{~h}$ at $37^{\circ} \mathrm{C}$. After this time, a disc of one-centimetre in diameter of 4 days old mould culture was cut using a cork borer and placed in between the two lines of $\mathrm{LAB}$ cultures and incubated at $28^{\circ} \mathrm{C}$ for several days. The experiment was conducted in triplicates and the control was the fungus cultivated without LAB presence (Fig. 1). The results were recorded from the third day. The percentage of mould inhibition was calculated using the following formula:

$$
\% \cdot \text { of } \cdot \text { mold } \cdot \text { inhibition }=\frac{D C-D T}{D C} \times 100
$$

where DC is the maximum colonization distance of the mould in the control plate and DT is the colonization distance on the test plate in presence of LAB.

\section{(3) Biochemical characterization of the antagonistic lactic acid bacteria}

After the evaluation of LAB inhibitory ability, others characteristics of the selected LAB strains with high antifungal activity were observed following the criteria proposed by Holzapfel \& al [15], Yimin \& al [16] and Kozaki \& al [17] on the degradation of carbon substrates and gas production (hydrogen sulphide and carbon dioxide). 


\section{(4) Molecular identification of the selected LAB isolates}

\section{DNA extraction}

LAB strains initially cultivated in MRS broth at $37^{\circ} \mathrm{C}$ for 48 hours were collected by centrifugation at $5000 \mathrm{rpm}$ for 5 minutes and the DNA extraction performed with QIAampcador Pathogen kit (Qiagen kit), based on the manufacturer's instructions. The obtained DNA was kept at $-4^{\circ} \mathrm{C}$.

\section{DNA Amplification}

The 16S of the rDNA were amplified by Polymerase Chain Reaction (PCR) using specific lactic acid bacteria primers LacF (5'-AGCAGTAGGGAATCTTCCA-3') and LacR (5'-ATTCCACCGCTACACATG-3') of 340 pairs of bases (RITCHIE et al 2010) according to the program proposed by Ponnusamy \& al [18]. The PCR reagents used in preparing the Mix-PCR comprised $1.5 \mathrm{mM}$ of $\mathrm{MgCl} 2$, $0.5 \mu \mathrm{M}$ of each primer, $0.025 \mathrm{U}^{-} \mathrm{l}^{-1}$ of DreamTaq DNA Polymerase (Thermo Scientific, USA), $0.2 \mathrm{mM}$ of dNTPs, and 10-30 ng $(10 \mu \mathrm{l})$ of DNA for a final volume of $50 \mathrm{ml}$. The PCR was conducted in a MultiGene thermocycler (Labnet International, USA) under the following experimental conditions: initial denaturation $\left(94^{\circ} \mathrm{C} / 2\right.$ minutes); 30 cycles of denaturation $\left(94^{\circ} \mathrm{C} / 15\right.$ seconds $)$, hybridization $\left(51^{\circ} \mathrm{C} / 15\right.$ seconds), elongation $\left(72^{\circ} \mathrm{C} / 30\right.$ seconds $)$; final elongation $\left(72^{\circ} \mathrm{C} / 7\right.$ minutes) [19]. The PCR products were checked on agarose gels $(2 \% \mathrm{~W} / \mathrm{V})$ stained with ethidium bromide $\left(7 \mu \mathrm{g} \cdot \mu \mathrm{l}^{-1}\right)$.

\section{DNA sequencing and sequence analysis}

Amplified DNA fragments were sequenced by BaseClear (The Netherlands) in both orientations using the primers LacF and LacR. The sequences obtained were analysed using NCBI blast (The National Center for Biotechnology Information) (https://blast.ncbi.nlm.nih.gov/Blast.cgi) for their identification and deposited in the NCBI database. The evolutionary history was inferred using the NeighborJoining method [20]. Evolutionary analyses were conducted in MEGA7 [21]. The phylogenetic tree included other lactic acid bacteria isolated from various media with known or unknown antifungal properties and available in the NCBI database.

\section{(5) Study of antifungal action mechanisms}

Preparation of cell-free culture supernatants

The preparation of Cell-free culture supernatants (CFCS) of selected antifungal strains was done as follows: LAB strains were propagated twice in MRS broth for $48 \mathrm{~h}$ at $30^{\circ} \mathrm{C}$. Then, the cells were removed from broth by centrifugation (5000 rpm, $15 \mathrm{~min}$ ) and supernatants filtered by $0.22 \mu \mathrm{m}$ pore size Millipore filters to obtain CFCS.
Effects of pH, temperature and proteolytic enzymes on cell-free culture supernatants inhibitory activity

The $\mathrm{pH}$ of each CFCS was adjusted to values of 5, 7, 9 and 11 with $0.1 \mathrm{~N} \mathrm{NaOH}$ and tested for the inhibitory performances. To determine the effect of heat on CFCS activity, the CFCS was treated at 60,80 and $100^{\circ} \mathrm{C}$ for 15 , 30, 60 min. For enzyme stability, CFCS was treated for $1 \mathrm{~h}$ with a pepsin, trypsin and proteinase $\mathrm{K}$ enzyme at a final concentration of $1 \mathrm{mg} \cdot \mathrm{ml}^{-1}$ [22]. The residual activity was determined by the agar well diffusion assay using $100 \mu \mathrm{l}$ of each treated and non-treated CFCS. The mixture was then assayed for inhibitory activity against Penicillium citrinum M8 and Aspergillus carbonarius NRRL 368.

Identification and quantification of organic acids produced

Chromatographic analysis was carried out using a WATERS ALLIANCE system with a 2695 separation module and a 2487 UV detector (Waters; Millipore, Milford, MA, USA). Analytic separation was achieved with SUPELCOGEL H column (250 mm x $4.6 \mathrm{~mm}$ ) fitted with SUPELCOGEL H Guard Column (50 mm x $4.6 \mathrm{~mm}$ ) using $0.1 \% \mathrm{H}_{3} \mathrm{PO}_{4}$ as mobile phase, with $0.17 \mathrm{ml} / \mathrm{min}$ flow. UV detection was performed at $210 \mathrm{~nm}$. Data were collected and analysed with the Empower 2.3 system (Waters Corporation, Milford MA, USA).

Organic acids were identified according to their retention times. Quantification was done according to the compounds peak area using a calibration curb obtained by injecting different volumes of a standard solution containing $30 \mathrm{ng} \cdot \mu \mathrm{l}^{-1}$ lactic acid, $50 \mathrm{ng} \cdot \mu \mathrm{l}^{-1}$ acetic acid, $25 \mathrm{ng} \cdot \mu \mathrm{l}^{-1}$ citric acid and $77 \mathrm{ng} \cdot \mu^{-1}$ gluconic acid.

\section{Statistical analysis}

Multidimensional datasets from antifungal activity were analyzed using principal component analysis (PCA, XLSTAT, 2007). All data were presented as mean of experiments performed in triplicate and were analysed by two-way analysis variance, and Tukey's test was applied for significant means at $\mathrm{p}<0.05$ to evaluate the significant differences.

\section{Results}

\section{Isolation of lactic acid bacteria}

A total of 28 bacterial colonies showing cultural characteristics specific to LAB group were isolated from fermentation and coded as follows: Lab1, Lab2, Lab3, Lab4, Lab5, Lab6, Lab8, Lab9, Lab10, Lab11.1, Lab 11.2, Lab 12, A11, A12, A13, A14, A15, A16, A17, A18, A19, A21, A22, A23, A24, A25, Ped2 and Ped3. 
All strains were analysed microscopically and macroscopically. They showed to be rods or cocci, Gram positive and immobile. Moreover, they were all catalase negative leading to a presumptive association to the LAB group (unpublished data).

\section{Antifungal properties of isolated LAB}

In the Table 1 and Fig. 1 is presented the antifungal activity of lactic acid bacteria. All bacterial isolates showed antifungal activity against the tested moulds, with different degrees of inhibition ranging from $6.82 \%$ to $100 \%$. The obtained data indicated that the isolate Lab 11.1 had the highest mean inhibition percentage against all the tested moulds in the range of $37.77-100 \%$, followed by A21 (30.85-100\%), Ped2 (29.60-68.00\%), Lab 9 (36.17-60.63\%), Lab10 (27.27-71.59\%), Ped3 (20.50-65.85\%), Lab11.2 (23.23-65.85\%) and A19 (20.19-72\%). It can be noticed that Lab 11.1 completely inhibited $(100 \%)$ the growth of two Penicillium strains (M7 and M8) and of A. niger and have highest activity against 5 of 10 fungal strains (Table 1).

a)

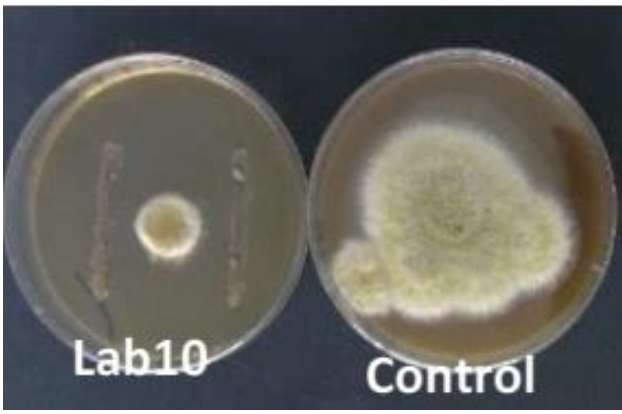

c)

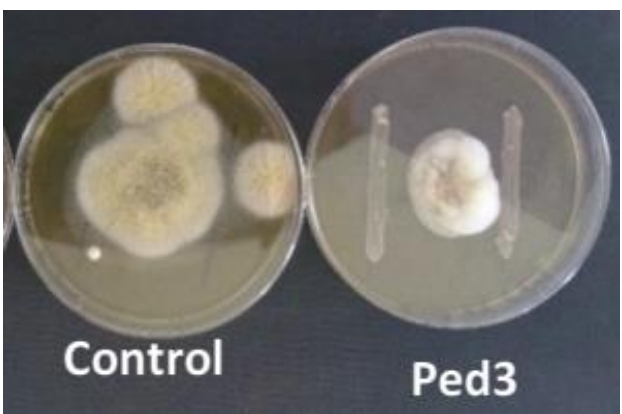

The Principal Component Analysis (PCA) method allowed to analyse the tested LAB antifungal activity according to two principal variable/axes (Fig. 2). According to the variables, two main Lab groups have been obtained (circles). The F1 axis explains $65.72 \%$ of the variations observed with a strong contribution percentage of LAB with high antifungal activity, respectively: Lab 11.1 (25.2\%), A21 (14.9\%), Lab 9 (5.6\%), Ped2 (4.6\%), Ped $3(3.7 \%)$, L. sanfranscisensis (3.5\%), Lab 10 (3.4\%), L. brevis (2.0\%), Lab11.2 (1.6\%), and L. plantarum (1.3\%). The F2 axis indicates $8.42 \%$ of this distribution with LAB proving strong activity: Lab 11.1 (21.43\%), A19 (9.28\%), Lab 2 (9.14\%), L. sanfranscisensis $(6.84 \%)$, L. brevis (6.48\%), and Lab 12 (5.14\%). It was noticed that the first group of LAB shows antifungal activity on the totality of the tested moulds contrary to the second group showing limited activity on different moulds species. Based on the antifungal screening data (Table 1), 8 LAB strains (Ped2; Ped3; Lab 9; Lab 10; Lab11.1; Lab 11.2; A19 and A21) with high antifungal activity were selected for the next detailed analysis.
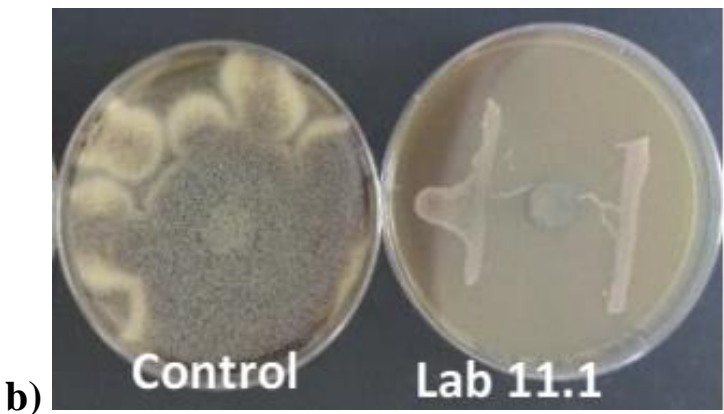

d)

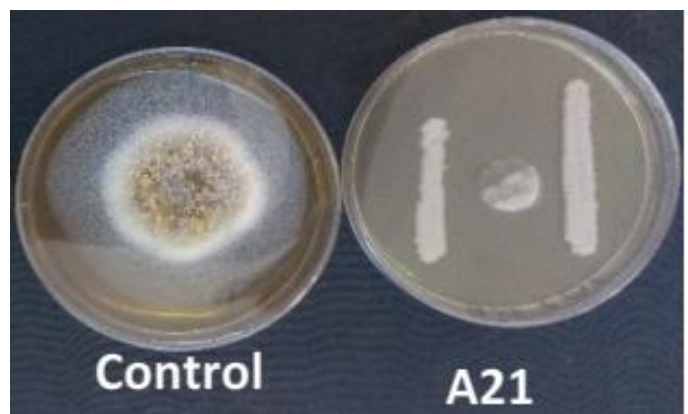

Figure 1. Aspects of mould growth inhibition by different lactic acid bacteria strains (Lab 10, A21, Ped 3 and Lab 11.1): a) A. oryzae M13; b) A. niger NRRL 612; c) A. versicolor M14; d) A. flavus AF.

\section{Biochemical characterisation of antifungal lactic acid bacteria strains}

The selected antifungal LAB strains were subject of some biochemical tests, helpful for strains identification and characterisation (Table 2). The results showed that all LAB strains have been capable to metabolize glucose, fructose, sucrose, maltose, lactose and cellobiose. None of them produce hydrogen sulphide. Differences between these strains were observed for the acid production from the fermentation of glycerol, arabinose, threhalose, raffinose, melibiose, ribose, esculin and carbon dioxide production when cultivated on glucose. These data are not sufficient to define the identity of the LAB but are useful for the correlation with the molecular identification results find out by sequencing. 
Table 1. Antifungal activity of LAB isolated from fermented cocoa beans.

Results are expressed as inhibition percentage (Supplementary data)

\begin{tabular}{|c|c|c|c|c|c|c|c|c|c|c|}
\hline & \multicolumn{10}{|c|}{ Moulds } \\
\hline & $\mathrm{AC}$ & AN & $\mathrm{AF}$ & M7 & M8 & M11 & M13 & M14 & M21 & M22 \\
\hline L. brevis & 50.62 & 27.27 & 26.66 & 65.85 & $\mathbf{3 7 . 5 0}$ & 47.85 & 34.61 & 51.06 & 22.72 & 68.00 \\
\hline L. Plantarum & 50.62 & 22.72 & 28.88 & 65.85 & $\mathbf{5 7 . 5 0}$ & 44.28 & 61.53 & 40.42 & 20.45 & 35.00 \\
\hline L. sanfranscisencis & 56.92 & 31.81 & 35.55 & 43.90 & 43.85 & 64.28 & 44.28 & 40.42 & 29.54 & 68.00 \\
\hline Lab 1 & 14.77 & 20.45 & 17.77 & 65.85 & 37.50 & 37.23 & 15.91 & 36.17 & 14.80 & 28.00 \\
\hline Lab 2 & 54.55 & 9.09 & 11.11 & 45.12 & 48.80 & 36.17 & 6.82 & 29.79 & 18.20 & 25.00 \\
\hline Lab 3 & 37.50 & 9.09 & 24.44 & 39.02 & 37.50 & 14.89 & 20.45 & 27.66 & 14.80 & 25.00 \\
\hline Lab 4 & 20.45 & 12.50 & 16.66 & 40.24 & 32.50 & 21.27 & 31.82 & 27.66 & 14.80 & 25.00 \\
\hline Lab 5 & 14.77 & 18.18 & 15.55 & 65.85 & 23.80 & 30.85 & 31.82 & 29.79 & 12.50 & 25.00 \\
\hline Lab 6 & 18.18 & 18.18 & 15.55 & 41.46 & 30.00 & 14.89 & 20.45 & 19.15 & 18.20 & 23.00 \\
\hline Lab 7 & 14.77 & 25.00 & 14.44 & 43.90 & 30.00 & 21.27 & 18.18 & 25.53 & 14.80 & 20.00 \\
\hline Lab 8 & 14.77 & 12.50 & 21.11 & 20.73 & 21.30 & 32.98 & 43.18 & 24.47 & 15.90 & 18.00 \\
\hline Lab 9 & 60.63 & 39.77 & 35.55 & 57.31 & $\mathbf{5 7 . 5 0}$ & $\mathbf{5 8 . 5 7}$ & 44.32 & 36.17 & 45.80 & 49.00 \\
\hline Lab 10 & 61.36 & 27.27 & 30.00 & 65.85 & 65.00 & 56.38 & 71.59 & 29.79 & 26.10 & 49.00 \\
\hline Lab 11.1 & 59.09 & 100.00 & 37.77 & 100.00 & 100.00 & 78.72 & 60.23 & $\mathbf{5 9 . 5 7}$ & 40.90 & 43.00 \\
\hline Lab 11.2 & 44.32 & 31.82 & 23.33 & 65.85 & $\mathbf{5 7 . 5 0}$ & 48.93 & 53.41 & 40.43 & 29.60 & 30.00 \\
\hline LAB12 & 20.45 & 29.55 & 11.11 & 51.22 & 25.00 & 32.98 & 44.32 & 29.79 & 29.60 & 25.00 \\
\hline A11 & 29.55 & 20.45 & 18.88 & 50.00 & 30.00 & 30.85 & 20.45 & 31.91 & 14.80 & 28.00 \\
\hline A12 & 22.73 & 14.77 & 18.88 & 39.02 & 28.80 & 30.85 & 44.32 & 21.28 & 18.20 & 25.00 \\
\hline A13 & 29.55 & 18.18 & 15.55 & 50.00 & 12.50 & 38.30 & 53.41 & 29.79 & 14.80 & 25.00 \\
\hline A14 & 20.45 & 14.77 & 17.77 & 39.02 & 17.50 & 14.89 & 21.59 & 17.02 & 9.09 & 28.00 \\
\hline A15 & 14.77 & 14.77 & 17.77 & 34.15 & 32.50 & 34.04 & 30.68 & 14.89 & 15.90 & 25.00 \\
\hline A16 & 14.77 & 12.50 & 17.77 & 50.00 & 23.80 & 14.89 & 20.45 & 24.47 & 15.90 & 25.00 \\
\hline A17 & 12.50 & 18.18 & 17.77 & 65.85 & 30.00 & 20.21 & 53.41 & 21.28 & 18.20 & 24.00 \\
\hline A18 & 12.50 & 27.27 & 16.66 & 36.59 & 30.00 & 28.72 & 44.32 & 29.79 & 15.90 & 25.00 \\
\hline A19 & 51.25 & 25.00 & 23.33 & 65.85 & $\mathbf{5 4 . 8 5}$ & 52.14 & 20.19 & 32.98 & 21.60 & 72.00 \\
\hline A 21 & 44.32 & 36.36 & 68.88 & 100.00 & 100.00 & 70.21 & 59.09 & 30.85 & 33.00 & 64.00 \\
\hline A22 & 22.73 & 18.18 & 13.33 & 39.02 & 27.50 & 27.66 & 20.45 & 30.85 & 17.10 & 28.00 \\
\hline A23 & 29.55 & 27.27 & 11.11 & 37.80 & 28.80 & 27.66 & 53.41 & 36.17 & 11.40 & 25.00 \\
\hline A25 & 20.45 & 12.50 & 18.88 & 39.02 & 35.00 & 27.66 & 44.32 & 32.98 & 17.10 & 25.00 \\
\hline Ped 2 & 56.82 & 36.36 & 35.55 & 65.85 & $\mathbf{5 7 . 5 0}$ & 51.06 & 44.32 & 40.43 & 29.60 & 68.00 \\
\hline Ped 3 & 44.32 & 31.82 & 35.55 & 65.85 & 37.50 & $\mathbf{5 9 . 5 7}$ & 63.64 & 51.06 & 20.50 & 64.00 \\
\hline Means & 32.90 & 24.63 & 23.01 & 53.42 & 40.37 & 37.75 & 38.61 & 32.05 & 20.70 & 35.71 \\
\hline
\end{tabular}

Legend: AC- Aspergillus carbonarius NRRL 368 UY1, AF - Aspegillus flavus, AN- Aspergillus niger NRRL 612, M7- Penicillium citrinum Ma, M8- Penicillium citrinum Md, M11-Aspergillus fumigatus, M13-Aspergillus oryzae, M14- Aspergillus versicolor, M21- Aspergillus tamarii, M22- Aspergillus versicolor. 


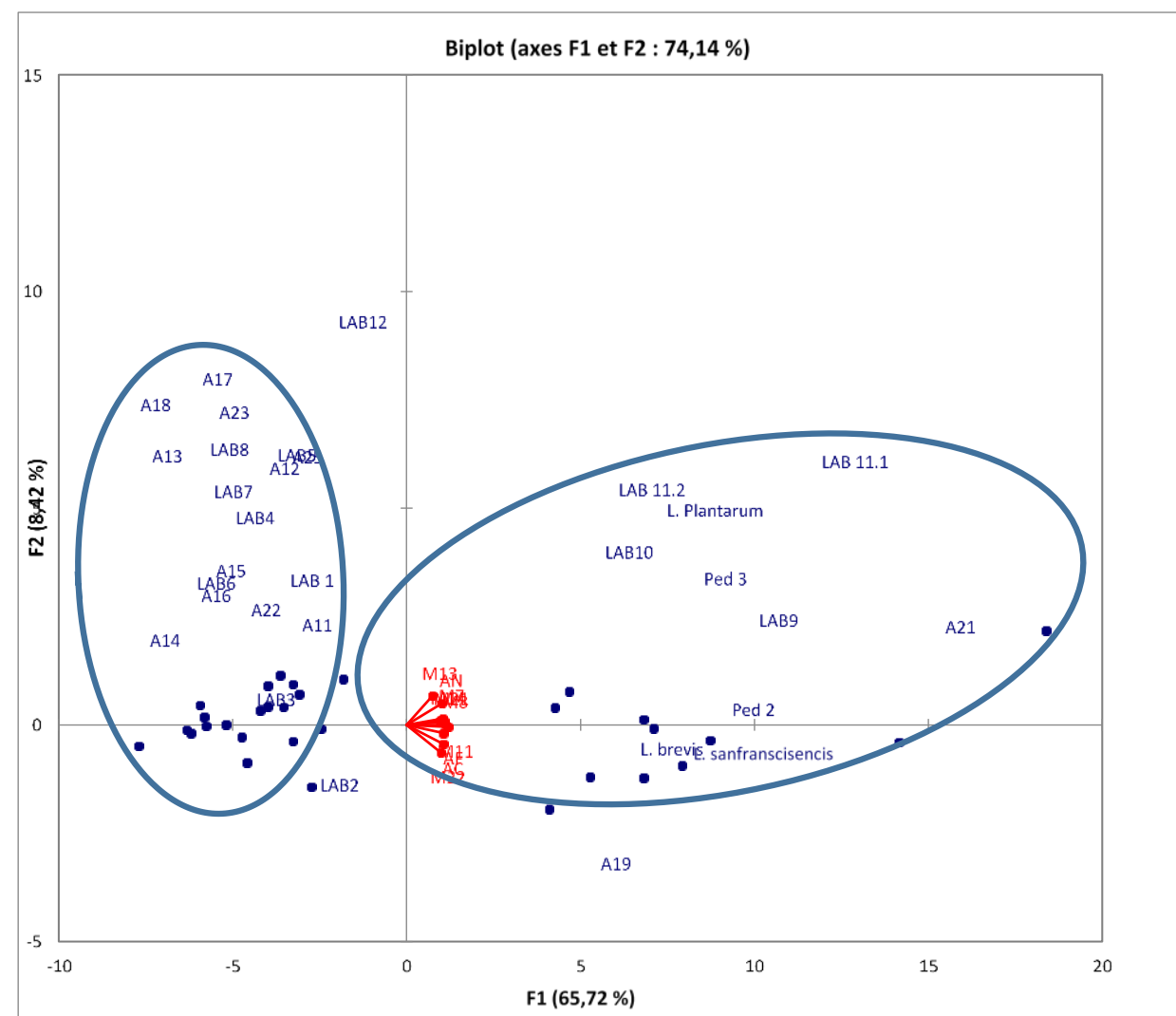

Figure 2. Principal component analysis showing a correlation circle projection of lactic acid bacteria.

Table 2. Biochemical characteristics of selected LAB strains

\begin{tabular}{|c|c|c|c|c|c|c|c|c|}
\hline Characteristics & Ped 2 & Ped 3 & Lab 9 & Lab 10 & $\begin{array}{l}\text { LAB } \\
11.1 \\
\end{array}$ & Lab 11.2 & A19 & A21 \\
\hline $\begin{array}{l}\mathrm{H}_{2} \mathrm{~S} \text { gas } \\
\text { production }\end{array}$ & - & - & - & - & - & - & - & - \\
\hline $\begin{array}{l}\mathrm{CO}_{2} \text { production } \\
\text { from glucose }\end{array}$ & + & - & - & + & - & - & + & + \\
\hline \multicolumn{9}{|c|}{ Carbohydrate fermentation } \\
\hline Glucose & + & + & + & + & + & + & + & + \\
\hline Glycerol & - & + & - & - & - & + & - & - \\
\hline D(-)Arabinose & + & + & - & + & - & + & + & + \\
\hline Galactose & - & + & + & - & + & + & - & + \\
\hline Fructose & + & + & + & + & + & + & + & + \\
\hline Sucrose & + & + & + & + & + & + & + & + \\
\hline Maltose & + & + & + & + & + & + & + & + \\
\hline Inositol & + & - & - & + & - & - & + & - \\
\hline Trehalose & - & + & + & - & + & + & - & - \\
\hline $\mathrm{D}(+)$ Raffinose & - & + & - & - & + & - & - & + \\
\hline Starch & + & + & - & + & + & + & + & - \\
\hline Lactose & + & + & + & + & + & + & + & + \\
\hline L-Rhamnose & + & - & + & + & - & - & + & + \\
\hline Cellobiose & + & + & + & + & + & + & + & - \\
\hline Mannitol & + & + & + & + & - & + & + & - \\
\hline Melibiose & - & + & + & - & - & + & - & - \\
\hline Ribose & - & + & + & - & - & + & - & - \\
\hline Xylose & + & - & + & + & - & - & + & + \\
\hline Esculin & + & + & - & + & + & + & + & + \\
\hline
\end{tabular}




\section{bacteria}

Molecular identification of selected lactic acid

All the strains have amplified a specific common fragment of $340 \mathrm{bp}$ with the specific lactobacilli primers Lac F and Lac R (Fig. 3). The sequences received from BaseClear (The Netherlands) were analysed via Blast search from NCBI database. High identities percentage matching with sequences from NCBI database obtained were 99-100\% similarity for Weissella cibaria (A19, Lab10 and Ped2), 99-100\% for Enterococcus faecium (Ped3 and Lab11.2), 99\% for Pediococcus pentosaceus (Lab9), 100\% for Lactobacillus brevis (A21), and 100\% for Lactobacillus farciminis (Lab11.1). Their NCBI access numbers are shown in Table 3 . The $16 \mathrm{~S}$ rDNA sequencing results identified different strains supporting value from bootstrap analysis in the phylogenetic tree (Fig. 4).

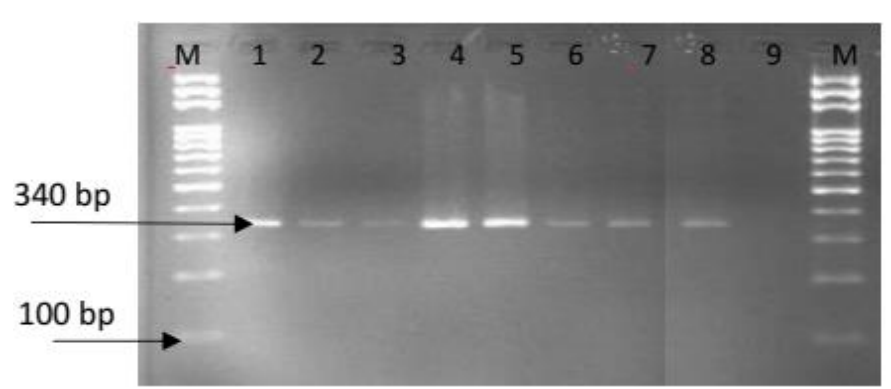

Figure 3. Fragments amplified with Lac F and Lac R primers $(340 \mathrm{bp})$ specific for lactobacilli (M-Time marker $100 \mathrm{bp}$ ladder, 1-Ped 2, 2-Ped 3, 3-Lab 9, 4-Lab 10, 5-Lab 11.1, 6-Lab11.2, 7-A19, 8-A21, 9-negative control).
Table 3. Strains accession number

\begin{tabular}{|ll|}
\hline Strains & $\begin{array}{c}\text { Accession } \\
\text { number }\end{array}$ \\
\hline Weissella cibaria Ped 2 & MN173224 \\
Enterococcus faecium Ped 3 & MN173225 \\
Pediococcus pentosaceus Lab 9 & MN173228 \\
Weissella cibaria Lab 10 & MN173229 \\
Lactobacillus farciminis LAB 11.1 & MN173230 \\
Enterococcus faecium Lab 11.2 & MN173231 \\
Weissella cibaria A19 & MN173226 \\
Lactobacillus brevis A21 & MN173227 \\
\hline
\end{tabular}

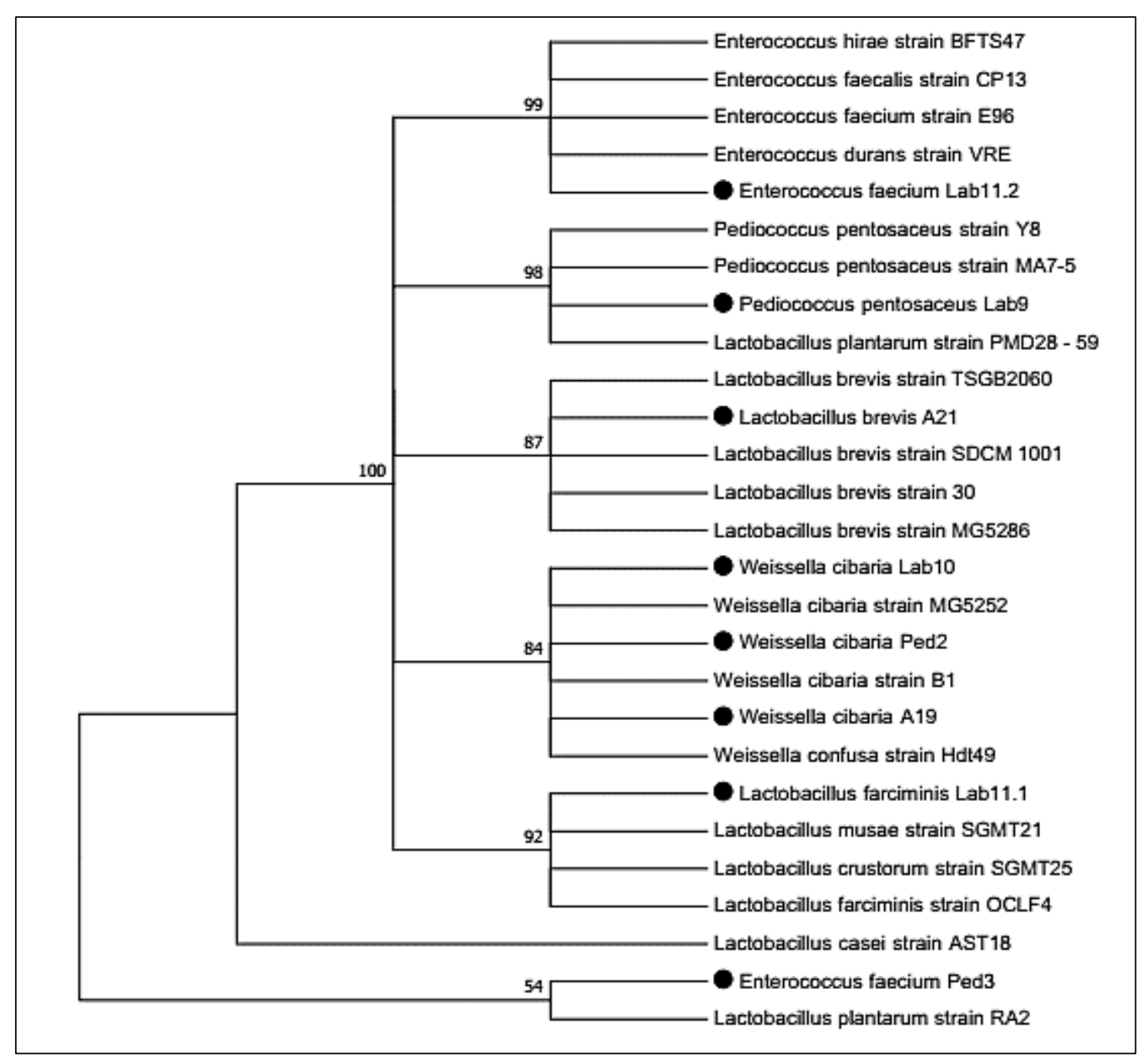

Figure 4. Phylogenetic tree of the 16S rRNA gene sequences obtained with group-specific primers Lactobacillus spp. 


\section{Study of antifungal action mechanisms}

Sensibility of CFCS to $\mathrm{pH}$, temperature and proteolytic enzymes treatments

After the cultivation of selected LAB, CFCS pH values were checked for each strain and they ranged from 3.5 to 4.5 . The performed experiments showed that treated or not treated CFCS still exhibited antifungal activities against tested fungi in comparison to the negative controls, and was the same for 6 of 8 antifungal LAB. However, treated CFCS of two strains of Enterococcus faecium (Ped 3 and Lab 11.2) are sensible to heat $\left(100^{\circ} \mathrm{C} / 10 \mathrm{~min}\right.$ minimum), to proteinase $\mathrm{K}$ and neutral $\mathrm{pH}$, in comparison to other strains (Table 4). This activity lost in the CFCS of Enterococcus faecium submitted to the heat treatment may appear due to the proteic nature of its antifungal compounds.

Table 4. Antifungal activity of CFCS after $\mathrm{pH}$, temperature and enzymes treatments

\begin{tabular}{|c|c|c|c|c|c|c|c|c|c|c|c|c|c|c|c|c|c|}
\hline & & \multicolumn{8}{|c|}{ Aspergillus carbonarius $\mathrm{AC}$} & \multicolumn{8}{|c|}{ Penicillium citrinum $\mathrm{M} 8$} \\
\hline & & $\begin{array}{l}\text { Ped } \\
2\end{array}$ & $\begin{array}{l}\text { Ped } \\
3\end{array}$ & $\begin{array}{l}\text { Lab } \\
9\end{array}$ & $\begin{array}{l}\text { Lab1 } \\
0\end{array}$ & $\begin{array}{l}\text { Lab11. } \\
1\end{array}$ & $\begin{array}{l}\text { Lab11. } \\
2\end{array}$ & $\begin{array}{l}\text { A1 } \\
9\end{array}$ & $\begin{array}{l}\mathrm{A} 2 \\
1\end{array}$ & $\begin{array}{l}\text { Ped } \\
2\end{array}$ & $\begin{array}{l}\text { Ped } \\
3\end{array}$ & $\begin{array}{l}\text { Lab } \\
9\end{array}$ & $\begin{array}{l}\text { Lab1 } \\
0\end{array}$ & $\begin{array}{l}\text { Lab11. } \\
1\end{array}$ & $\begin{array}{l}\text { Lab11. } \\
2\end{array}$ & $\begin{array}{l}\text { A1 } \\
9\end{array}$ & $\begin{array}{l}\mathrm{A} 2 \\
1\end{array}$ \\
\hline negative & Control & - & - & - & - & - & - & - & - & - & - & - & - & - & - & - & - \\
\hline \multirow{4}{*}{$\begin{array}{l}\text { Positive } \\
\text { Enzymes } \\
\text { treatment }\end{array}$} & Control & + & + & + & + & + & + & + & + & + & + & + & + & + & + & + & + \\
\hline & Trypsin & + & + & + & + & + & + & + & + & + & + & + & + & + & + & + & + \\
\hline & Pepsine & + & + & + & + & + & + & + & + & + & + & + & + & + & + & + & + \\
\hline & $\begin{array}{c}\text { Proteinase } \\
\text { K }\end{array}$ & + & - & + & + & + & - & + & + & + & - & + & + & + & - & + & + \\
\hline \multirow{4}{*}{$\begin{array}{c}\mathrm{pH} \\
\text { treatment }\end{array}$} & 5 & + & + & + & + & + & + & + & + & + & + & + & + & + & + & + & + \\
\hline & 7 & + & - & + & + & + & - & + & + & + & - & + & + & + & - & + & + \\
\hline & 9 & + & - & + & + & + & - & + & + & + & - & + & + & + & - & + & + \\
\hline & 11 & + & - & + & + & + & - & + & + & + & - & + & + & + & - & + & + \\
\hline \multirow[t]{3}{*}{$60^{\circ} \mathrm{C}$} & $10 \mathrm{~min}$ & + & + & + & + & + & + & + & + & + & + & + & + & + & + & + & + \\
\hline & $30 \mathrm{~min}$ & + & + & + & + & + & + & + & + & + & + & + & + & + & + & + & + \\
\hline & $60 \mathrm{~min}$ & + & + & + & + & + & + & + & + & + & + & + & + & + & + & + & + \\
\hline \multirow[t]{3}{*}{$80^{\circ} \mathrm{C}$} & $10 \mathrm{~min}$ & + & + & + & + & + & + & + & + & + & + & + & + & + & + & + & + \\
\hline & $30 \mathrm{~min}$ & + & + & + & + & + & + & + & + & + & + & + & + & + & + & + & + \\
\hline & $60 \mathrm{~min}$ & + & + & + & + & + & + & + & + & + & + & + & + & + & + & + & + \\
\hline \multirow[t]{3}{*}{$100^{\circ} \mathrm{C}$} & $10 \mathrm{~min}$ & + & - & + & + & + & - & + & + & + & - & + & + & + & - & + & + \\
\hline & $30 \mathrm{~min}$ & + & - & + & + & + & - & + & + & + & - & + & + & + & - & + & + \\
\hline & $60 \mathrm{~min}$ & + & - & + & + & + & - & + & + & + & - & + & + & + & - & + & + \\
\hline
\end{tabular}

- absence of antifungal activity following treatmen

+ detected antifungal activity following treatment

Identification and quantification of organic acids

In order to evaluate which organic acids with antifungal potential were present in the supernatant, a number of compounds were targeted for the detection and quantification by HPLC analysis. The highest producer of lactic acid is Pediococcus pentosaceus (Lab 9) with $21.419 \mu \mathrm{g} . \mu \mathrm{l}^{-1}$ followed by $L$. farciminis (Lab 11.1) (19.46 $\left.\mu \mathrm{g} . \mu \mathrm{l}^{-1}\right)$, while the lowest producer is $L$. brevis (A21) with $11.63 \mu \mathrm{g} . \mu \mathrm{l}^{-1}$. Acetic acid was not detected in all samples (Table 5). Only Pediococcus pentosaceus (Lab 9) and Weissella cibaria (A19) showed smaller amounts of gluconic acid in the range of 2.278 and $1.052 \mu \mathrm{g} . \mu \mathrm{l}^{-1}$ respectively.

Table 5. Quantification of organic acids by HPLC

\begin{tabular}{lcccccccc}
\hline Organic acids & Ped2 & Ped3 & Lab 9 & Lab 10 & Lab 11.1 & Lab 11.2 & A19 & A21 \\
\hline Lactic acid $\left(\mu \mathrm{g} . \mu \mathrm{l}^{-1}\right)$ & 18.815 & 17.527 & 21.419 & 16.71 & 19.466 & 16.625 & 13.432 & 11.639 \\
Acetic acid $\left(\mu \mathrm{g} \cdot \mu \mathrm{l}^{-1}\right)$ & 0 & 0 & 0 & 0 & 0 & 0 & 0 & 0 \\
Gluconic acid $\left(\mu \mathrm{g} \cdot \mu 1^{-1}\right)$ & 0 & 0 & 2.278 & 0 & 0 & 0 & 1.052 & 0 \\
Citric acid $\left(\mu \mathrm{g} \cdot \mu \mathrm{l}^{-1}\right)$ & 0 & 0 & 0 & 0 & 0 & 0 & 0 & 0 \\
\hline
\end{tabular}

\section{Discussion}

The conservation of cocoa beans against moulds remains mainly a major challenge. Indeed, the visible presence of moulds in cocoa beans leads to their depreciation and rejection by chocolate maker whether or not these strains produce mycotoxins. Moulds can contaminate cocoa processing at different stages, making the improvement of the practices difficult to implement satisfactorily. Therefore, the inoculation of antifungal LAB strains in to cocoa bean fermenting masses has been taken into account as a putative application of biological control. Thus, cocoa fermentations could be a reservoir of LAB to be selected for their use as antifungal agent or starter cultures [12, 23]. Therefore, it has been reported that the use LAB with 
antifungal properties, could be a considerable advantage if cocoa beans were initially inoculated with them [10].

In this study, our targets consisted of moulds species commonly encountered in fermented and or dried cocoa beans environments [10, 24]. All the $28 \mathrm{LAB}$ isolates were observed to have different antifungal potential, but at the end, only 8 have been selected for their higher and stable activity against the tested moulds. The most sensitive moulds were Penicillium citrinum (M7 and M8) and A. niger NRRL 612 which were inhibited up to $100 \%$ by Lactobacillus farciminis Lab11.1 and Lactobacillus brevis A21 strains, while the most resistant were A. carbonarius NRRL 368 and A. tamarii M21. These results are in agreement with those of Gerez \& al [25], Matei and Cornea [11] and Ouattara \& al [23]. They have reported that Penicillium species are more sensitive to bacterial active molecules compared to moulds of the genus Aspergillus. However, by analysing the general data obtained on the antifungal activity of lactic acid bacteria, it was found that some species such as $P$. citrinum, A. versicolor presented have different sensitivity level. This could be due to the fact that different serotypes may be found in the same species as demonstrated by Sharma \& al [26]. At the same moment, the variability of active or sensible strains in the same species can be explained by the presence of several morphotypes that may have different characteristics in the same environment, as described by Tareb \& al [27] in the case of Lactobacillus farciminis or by Ayo-Olalusi [28] in the case of Pediococcus pentosaceus. In complement, PCA variables explain $74.14 \%$ of the variation between $\mathrm{LAB}$ on two virtual axes F1 and F2. The importance contribution of Lactobacillus farciminis (Lab11.1) on the two axes F1 and F2 is explained by its strong antifungal effect because it presented $100 \%$ of inhibition growth against three of ten tested moulds. It would thus be adapted within the framework of an antifungal control.

Antifungal LAB strains have the capacity to metabolize glucose, fructose, sucrose, maltose, lactose, cellobiose; none of them produce hydrogen sulphide. Differences between these strains were observed for production of acid from fermentation of glycerol, arabinose, threhalose, raffinose, melibiose, ribose, esculin and carbon dioxide from glucose fermentation. These characteristics are consistent with those reported by Fusco et al [29] for Weissella cibaria, by Tsuda \& al [30] for Lactobacillus farciminis, by Baradaran \& al [31] for Pediococcus pentosaceus, by Manero and Blanch [32] for Enterococcus faecium and by Gandevia \& al [33] for Lactobacillus brevis.

The molecular identification of these lactic bacteria revealed that the isolates belong to the $\mathrm{LAB}$ group such as Weissella cibaria (Lab10, A19 and Ped2), Pediococcus pentosaceus (Lab 9), Lactobacillus brevis (A21), Lactobacillus farciminis (Lab11.1) and Enterococcus faecium (Lab11.2 and Ped3). These results confirm those of other researchers who found LAB species like Lactobacillus, Leuconostoc, Lactococcus, Pediococcus, and Enterococcus in the fermentation of cocoa beans in Ghana, Nigeria, Ivory Coast and Cameroon [6, 23, 34].
The antagonist activity of different strains identified has been recognized by several authors. The most commonly cited strains in the literature remain Pediococcus pentosaceus, Lactobacillus brevis and Weissella cibaria for their antimicrobial activity against mould, and other pathogens. Relatively to their ability to produce many molecules, they have already found several applications in the food and medical industries and are already marketed in several forms. No studies have been found reporting the presence of Lactobacillus farciminis (which has the best inhibitory activity against the tested targets in cocoa beans fermentation. However, it is known for its probiotic character applied to animal feed [11, 27] and could therefore be exposed. On the other hand, Enterococcus faecium is not widely used, although it has been recognized as a producer of a bacteriocin known as enterocin [35].

Some hypotheses and evidence have been reported to explain this phenomenon of inhibition by the synergic effect of organic acids and other molecules [23, 36]. The variable inhibitory activity of LAB is attributed to a number of antimicrobial metabolites such as hydrogen peroxide, reuterin, phenyllactic acid, protein compounds, phenolic compounds and hydroxy fatty acids that have also been isolated from LAB [13, 37, 38].

$\mathrm{LAB}$ has been recognized to have antifungal activity. This study observed that the supernatants of the eight antifungal LAB isolated from cocoa beans had good antifungal activity against $A$. carbonarius and $P$. citrinum. This specifies that CFCS from these LAB isolates comprise of compounds with protein-like nature. When the CFCS was heated, their inhibited the growth of the by the heated CFCS. However, treated CFCS of two strains Enterococcus faecium are sensible to heat $\left(100^{\circ} \mathrm{C} / 10 \mathrm{~min}\right.$ minimum). Similarly, Magnusson \& al [39] and Laref \& al [40] observed that antifungal activity of lactic acid bacteria isolated from fermented food was stable during heat treatment and retaining the activity was even after autoclaving at $121^{\circ} \mathrm{C}$ for $15 \mathrm{~min}$ against moulds.

When the $\mathrm{pH}$ of the CFCS was adjusted to different value 5, 7, 9 and 11, antifungal activity stay constant. This observation shows that the compounds responsible for antifungal activity in CFCS of these isolates could not be only organic acids like acetic acid and lactic acid. The antifungal activity of CFCS treated with enzymes proteinase $\mathrm{K}$, pepsin and trypsin results were also stable. But treating CFCS with heat higher than $100^{\circ} \mathrm{C} / 10 \mathrm{~min}$, proteinase $\mathrm{K}$ and $\mathrm{pH} \mathrm{7,9}$ and 11 losed the antagonist activity of Enterococcus strains. Ndagano \& al [41] reported that supernatant treatment of LAB isolated from Mill flour and fermented cassava by pepsin, $\alpha$ chymotrypsin and proteinase $\mathrm{K}$ showed antifungal activity. These results suggest that the antifungal compound could be not only of proteinic nature. Considering different information on treated CFCS, the acid lactic amount and the presence of bands in different CFCS, it should be noted that synergistic effects may exist between molecules at low concentrations with an mechanism.

These results are very interesting and suggest that some LABs isolated from cocoa fermentation could be 
a promising candidate for food bio conservation applications. Considering our results, Lactobacillus farciminis can be recommended for cocoa beans fermentation for its highest anti-microbial potential among the isolates. However, all the isolated LAB should be taken into account as biocontrol agents, as also reported by Braiek \& al [42]; their application may depend on the spectra of spoilage microorganisms present in the cocoa beans' fermentation media, linked most probably to the environmental conditions and beans storage; more studies are requested in this regard.

\section{Conclusion}

In this study, it has been found that lactic acid bacteria strains, isolated from cocoa beans fermentation have a broad spectrum of inhibitory activity towards fungi. They have been identified as belonging to the species Weissella cibaria, Pediococcus pentosaceus Lactobacillus farciminis, Enterococcus faecium and Lactobacillus brevis. Their antifungal potential would be attributed to a synergic action of lactic acid, proteaginous compounds or unknown mechanisms. The promising characteristics of the different strains suggest their potential for food bio conservation to avoid product contamination, the proliferation of moulds present on cocoa beans. However, further experiments are needed to confirm these possibilities in cocoa fermentation.

\section{Acknowledgement}

This study was conducted with the support of the University Agency of Francophonie (AUF) through its program "Eugen Ionescu" funded by the Romanian Government to whom we are grateful. We also thank Food Microbiology research team of the Scienzedegli Alimenti (Cesena campus) of the University of Bologna and ARS strain collection of the National Center for Agricultural Utilization Research, USA.

\section{Conflict of interest}

The authors declare that they have no competing interests, financial or otherwise.

\section{References}

1. MULONO A, SUTARDI, SUPRIYANTO, ENI H. Study on effect of fermentation to the quality parameter of cocoa bean in Indonesia. Asian J. of Dairy \& Food Res. 35 (2), 160-163 (2016).

2. LEFEBER T, JANSSENS M, CAMU N, DE VUYST L. Kinetic analysis of strains of lactic acid bacteria and acetic acid bacteria in cocoa pulp simulation media toward development of a starter culture for cocoa bean fermentation. Appl. and Env. Microbio. 76, 7708-7716 (2010).

3. TAGRO G, SOUMAILA D, BAN-KOFFI L, KRAKEDJEBO D, IRIE GBZ. Effect of turning beans and fermentation method on the acidity and physical quality of raw cocoa beans. Adv J of Food Sci. and Tech. 45, 163-171(2010).
4. KRESNOWATI MTAP, SETIADI T, TANTRA TM, RUSDI D. Microbial production of xylitol from palm oil empty fruit bunches hydrolysate: effects of initial cell concentration and $\mathrm{pH}$. International seminar on biorenewable resources utilization for energy and chemicals, Bandung, Indonesia (2013).

5. ARDHANA M, FLEET G. The microbial ecology of cocoa bean fermentations in Indonesia. Int. J. of Food Microbiol. 86, 87-990 (2003).

6. CAMU N, DE WINTER T, VERBRUGGHE $\mathrm{K}$, CLEENWERCK I, VANDAMME P, TAKRAMA JS, VANCANNEYT M, DE VUYST L. Dynamics and biodiversity of populations of lactic acid bacteria and acetic acid bacteria involved in spontaneous heap fermentation of cocoa beans in Ghana. Appl and Env. Microbiol. 73, 1809-1824 (2007).

7. CAMU N, GONZALEZ A, DE WINTER T, VAN SCHOOR A, DE BRUYNE K, VANDAMME P, TAKRAMA JS, DE VUYST L. Influence of turning and environmental contamination on the dynamics of lactic acid bacteria and acetic acid bacteria populations involved in spontaneous cocoa bean heap fermentation in Ghana. Appl and Env. Microbiol. 74, 86-98 (2008).

8. CHELACK WS, BORSA J, MARQUARDT R, FROHLICH AA. Role of the competitive microbial flora in the radiation-induced enhancement of ochratoxin production by Aspergillus alutaceus var. alutaceus NRRL 3174. Appl and Env. Microbiol. 57, 2492-2496 (1991).

9. TAGRO SG, YAO MK, KOFFI-NEVRY, N'DRI DY, NIAMIEN PM. Enumeration and identification of main fungal isolates and evaluation of fermentation's degree of ivorian raw cocoa beans. Austral. J. of Basic and Appl. Sci. 1, 479-486 (2007).

10. ESSIA NGANG J-J, YADANG G, SADO KAMDEM SL, KOUEBOU CP, YOUTÉ FANCHÉ SA, TSOCHI KOUGAN DL, TSOUNGUI A, ETOA F-X. Antifungal properties of selected lactic acid bacteria and application in the biological control of ochratoxin A producing fungi during cocoa fermentation. Biocontr. Sci. and Technol. 25, 245-259 (2015).

11. MATEI A, CORNEA CP. Evaluation of antifungal activity of selected lactic acid bacteria strains against spoilage mould Penicillium expansum. Scientific Bulletin. Series F. Biotechnol. 19, 292-297 (2015).

12. RUGGIRELLO M, NUCERA D, CANNONI M, PERAINO A, ROSSO F, FONTANA M, COCOLIN L, DOCLI P. Antifungal activity of yeasts and lactic acid bacteria isolated from cocoa bean fermentations. Food Res. Int. 115, 519-525 (2019).

13. TATSADJIEU LN, TCHIKOUA R, MOSES CFM. Antifungal activity of lactic acid bacteria against molds isolated from corn and fermented corn paste. Ameri. J. of Microbiol Res. 4(4), 90-100 (2016).

14. LAREF N, GUESSAS B. Research article antifungal activity of newly isolates of lactic acid bacteria. Innovat. Rom. Food Biotechnol. 13: 80-88 (2013).

15. HOLZAPFEL WH, FRANZ CMAP, LUDWIG W, BACK W, DICK LMT. The genera pediococcus and tetragenococcus. In M. Dworkin, S. Falkow, E. Rosenberg, K.-H. Schleifer, \& E. Stackebrandt (Eds.), The prokaryotes, a handbook on the biology of bacteria $3^{\text {rd }}$ edts, p. 387 (2006). 
16. YIMIN C, SUMIO K, MASUHIRO O, YOSHIMI B, TAKASHI N. Characterization and identification of Pediococcus species isolated from forage crops and their application for silage preparation. Appl. and Env. Microbiol. 65, 2901-2906 (1999).

17. KOZAKI M, UCHIMURA T, OKADA S. Experimental manual of lactic acid bacteria. Tokyo, Japan: Asakurasyoten, 34-37 (1992).

18. PONNUSAMY K, CHOI JN, KIM J, LEE S, LEE $\mathrm{CH}$. Microbial community and metabolomic comparison of irritable bowel syndrome faeces. J. of Med. Microbiol. 60, 817-827 (2011).

19. MATEI B, SALZAT J, DIGUȚĂ CF, CORNEA CP, LUȚA G, UTOIU ER, MATEI F. Lactic acid bacteria strains isolated from Kombucha with potential probiotic effect. Rom. Biotechnol. Lett. 23 (3), 13592-13598 (2018).

20. SAITOU N, NEI M. The Neighbor-joining Method: A new method for reconstructing phylogenetic trees. Mol. Biol. and Evol. 4, 406-425 (1987).

21. TAMURA K, NEI M., KUMAR S. Prospects for inferring very large phylogenies by using the Neighborjoining method. Proceed. of National Acad. of Sci. 101, 11030-11035 (2004).

22. TZU-HSING L, TZU-MING P. Characterization of an antimicrobial substance produced by Lactobacillus plantarum NTU 102. J. of Microbiol., Immunol. and Infect. 52, 409-417 (2019).

23. OUATTARA DH, OUATTARA HG, DROUXB M, REVERCHONB S, NASSERB W, NIAMKEA SL. Lactic acid bacteria involved in cocoa beans fermentation from Ivory Coast: Species diversity and citrate lyase production. International J. of Food Microbiol. 256, 11-19 (2017)

24. VISINTIN S, ALESSANDRIA V, VALENTE A, DOLCI P, COCOLIN L. Molecular identification and physiological characterization of yeasts, lactic acid bacteria and acetic acid bacteria isolated from heap and box cocoa bean fermentations in West Africa. Int. J. of Food Microbiol. 216, 69-78 (2016).

25. GEREZ CL, CARBAJO MS, ROLLÁN G, TORRES MJ, FONT DE VALDEZ G. Inhibition of citrus fungal pathogens by using lactic acid bacteria. J. of Food Sci. 75, 354-359 (2010).

26. SHARMA P, MAHERCHANDANIA S, SHRINGIA BN, KASHYAPA SK, SUNDAR KSG. Temporal variations in patterns of Escherichia coli strain diversity and antimicrobial resistance in the migrant Egyptian vulture. Infect. Ecol. \& Epidemiol. 8, 1-11 (2018).

27. TAREB R, BERNARDEAU M, HORVATH P, VERNOUX J-P. Rough and smooth morphotypes isolated from Lactobacillus farciminis CNCM I-3699 are two closely-related variants. Int. J. of Food Microbiol. 193, 82-90 (2015).

28. AYO-OLALUSI CI. Isolation and identification of probiotics Pediococcus pentosaceus 2 and Pediococcus pentosaceus 1 from the gut of tilapia guineensis for use in aquaculture production. Int. J. of Res. Studies in Microbiol. and Biotechnol. 3, 15-20 (2017).
29. FUSCO V, QUERO GM, CHO G-S, KABISCH J, MESKE D, NEVE H, BOCKELMANN W, FRANZ CMAP. The genus Weissella: taxonomy, ecology and biotechnological potential. Frontiers in Microbiol. 6, 1-22 (2015).

30. TSUDA H, KUBOTA K, MATSUMOTO T, ISHIMI Y. Isolation and identification of lactic acid bacteria in traditional fermented sushi funazushi, from japan. Food Sci. and Technol. Res. 18, 77-82 (2012).

31. BARADARAN A, LING FOO H, SIEO CC, RAHIM R.A. Isolation, identification and characterization of lactic acid bacteria from Polygonum minus. Rom. Biotechnol. Lett. 17: 7245-7252 (2012).

32. MANERO A, BLANCH A. Identification of Enterococcus spp. with a Biochemical Key. Appl and Env. Microbiol. 65, 4425-4430 (1999).

33. GANDEVIA HA, RANA ND, DESAI BA. Screening, production and antibacterial activity of bacteriocin from Lactobacillus spp. BMR Microbiol. 3, 1-8 (2017).

34. KOSTINEK M, BAN-KOFFI L, OTTAH-ATIKPO M, TENIOLA D, SCHILLINGER U, HOLZAPFEL WH, FRANZ CMAP. Diversity of predominant lactic acid bacteria associated with cocoa fermentation in Nigeria. Curr. Microbiol. 56, 306-314 (2008).

35. FRANZ CMAP., BELKUM MJV, HOLZAPFEL WH, ABRIOUEL H, GALVEZ A. Diversity of enterococcal bacteriocins and their grouping in a new classification scheme. FEMS Microbiol. Rev. 31, 293-310 (2007).

36. DALIÉ DKD, DESCHAMPS AM, RICHARDFORGET F. Lactic acid bacteria - Potential for control of mould growth and mycotoxins: A review. Food Contr. 21, 370-380 (2010).

37. SCHNURER J, MAGNUSSON J. Antifungal lactic acid bacteria as biopreservatives. Trends in Food Sci. and Technol. 16, 70-78 (2007).

38. FOSSI BT, ACHIDI AU, TIENCHEU B, BILLE EY, TAKOP GN, AKWANWI CM, WANJI S. Optimisation of inhibitory activity of lactic acid bacteria against ochratoxin A producing moulds isolated from cocoa using response surface methodology. Eur. J. of Biotechnol and Biosci. 4(12), 17-26 (2016).

39. MAGNUSSON J, STRÖM K, ROOS S, SJÖGREN J, SCHNÜRER J. Broad and complex antifungal activity among environmental isolates of lactic acid bacteria. FEMS Microbiol. Lett. 219, 129-135 (2003).

40. LAREF N, BATTACHE G, KIHAL M. Antifungal compounds production in different temperatures, $\mathrm{pH}$ and on modified MRS agar by Lactobacillus strains. J. of Biol. Sci. 13, 94-99 (2013).

41. NDAGANO D, LAMOUREUX T, DORTU C, VANDERMOTEN S, THONART P. Antifungal activity of 2 lactic acid bacteria of Weissella genus isolated from food. J. of Food Sci. 76, 305-311 (2011).

42. BRAÏEK OB, CREMONESIC P, MORANDID S, SMAOUI S, HANIF K, GHRAIRIA T. Safety characterisation and inhibition of fungi and bacteria by a novel multiple enterocin-producing Enterococcus lactis 4CP3 strain. Microbial Pathogen. 118, 32-38 (2018). 